\title{
The Potency of Ulin (Eusideroxylon zwageri T. et. B) for Supporting Banjarese Building Construction in "Wetland Architecture"
}

\author{
YUDI FIRMANUL ARIFIN AND DANIEL ITTA
}

\begin{abstract}
Environmental condition of around rivers and swamps causes the Banjarese people to build settlements use ulin (Eusideroxylon zwageri T. et. B.). Using ulin has become their culture, because they believe the building will be stronger. In fact the potential ulin from year to year continues to decline, because the growth is not proportional to the speed of ulin needs for construction, thus it is becoming scarce. This research was conducted in Kabupaten Tanah Laut and Kabupaten Kotabaru. The method used survey with purposive sampling (large of sample plot $100 \mathrm{~m}$ x $100 \mathrm{~m}$ which each plot divided into 25 sub-plots of $20 \mathrm{~m}$ x $20 \mathrm{~m}$ ). All growth stages of ulin were inventoried and in each plot found ulin measured micro climate and collected sample of soil. Normally ulin can grow well on un-fertile soil, but micro climate like primary forest or old secondary forest. Potential ulin in both Kabupaten per hectare is very low. The amount of natural regenerations ranged from 3-5 individuals/ha for seedling and 3-46 individuals/ha for sapling. Number of poles found in both locations are ranged 5-6 individuals/ha, and not found tree stage. Restrictions on harvesting and conservation of ulin are urgently needed in South Kalimantan.
\end{abstract}

Keywords: ulin, wetland, potency, Banjarese building, construction

\section{INTRODUCTION}

Ironwood (Eusideroxilon zwageri T. et. B.) is locally known as ulin, belian, or tembelian. This heaviest and most durable native species known as Indonesian ironwood, have been used since hundred of years by community around the forest for various purposes such as wooden roof known as "siraf", doors, floors, frames of doors and windows, bridges, platform for small harbor, and ornaments in front of a house.

Since past time, all Banjarese activities depend on river even to this day. One of prominent is the dependence of economic activities such as trade, livelihoods, and transportation. Environmental condition or habitat of the rivers and swamp have been shaped the culture of Banjarese and known as the river-culture community. For this reason, all elements of Banjarese culture can be traced the with relation to the river environment (Muchamad and Mentayani, 2010).

Correspondence: Yudi Firmanul Arifin, Faculty of Forestry, Lambung Mangkurat University, Banjarbaru, Indonesia

Email: yudifirmanul@yahoo.com
Physically, the wetland environment affects the system of building construction. The effects of wetland environment on the building can be seen in some parts of the house of Banjarese in the "wetland architecture" (Muchamad and Mentayani, 2010). The contruction of the foundation of Banjarese houses, especially the high ridge house, is a form of physical culture of people living within the wetland (swamp). For a lighter weight of building, kacapuri foundation system is used. This system uses a smaller block of wood, generally ironwood (ulin), because this wood is very strength and high durability. For wall construction and roof are made of ironwood as well.

In order to keep the sustainable of ulin, the Government of Indonesia prohibits large forest concession holders to cut this particular species and only local people are given permission to cut the trees with diameter more than $60 \mathrm{~cm}$. However due to lack of control and high demand of local market and export, many trees below allowable diameter were still cut. At present, the potency and distribution of ulin is alarmingly getting lesser (Effendi, 2004). Due to very slow growth, at 
present, no investor is interested in establishing large scale ulin plantation even though the price is as high as Rp. 1,000,000,(US\$ 1,200$)$ per $\mathrm{m}^{3}$ at local market.

The objective of this study is to obtain data and information on ulin natural regeneration, potency, and structure composition of stand around ulin in South Kalimantan. This study can become information the real condition of ulin in field, especially in South Kalimantan.

\section{MATERIALS AND METHODS}

The locations of study are Kintap, Tanah Laut District and Serongga, Kotabaru District, South Kalimantan. Ulin grows naturally in both locations where included in lowland old secondary forest. The topography of the areas is undulating and hilly. Ulin can grow naturally at an altitude of up to $400 \mathrm{~m}$ above see level (Heyne, 1987).

A plot at KDTH Kintap tropical forest measuring 1 ha $(100 \mathrm{~m} \times 100 \mathrm{~m})$ was divided into 25 sub-plots ( $20 \mathrm{~m} \times 20 \mathrm{~m}$ each). The same number and size of plots was established in Serongga tropical production forest. The totals of plots are 2 plots or 50 sub-plots. The slope of plot 1 is relatively flat and plot is 2 of $18 \%$.

In both plots are mapped the distribution of regenerations and mature trees of ulin as well.

To describe the real habitat of ulin the micro climate was measured in the plots. To know the fertility of soil for each plot, soil chemical analysis was done.

\section{RESULTS}

Description of ulin habitat.Based on soil analysis, the soil $\mathrm{pH}$ under ulin trees is considered as acidic with $\mathrm{pH}$ ranged from 4.25-4.31 $\left(\mathrm{H}_{2} \mathrm{O}\right)$. The content of organic matter is $0.55-1.19 \%$. Based on USDA classification, the soil texture belong to dusty clay loam (DCL). Result of research in East Kalimantan that ulin grows at the $\mathrm{pH}$ 5.2-5.8 and organic matter content ranged from 1.83$3.21 \%$, respectively (Effendi, 2004), meanwhile ulin grows in soil having sandy loam texture with low soil fertility in South Sumatra (Nugroho et al., 2006).

Result of measured of micro climate under the forest stands, the regeneration of ulin found with temperature of $27.12^{\circ} \mathrm{C}-31.00^{\circ} \mathrm{C}$, humidity of $66.43 \%-83.76 \%$, and light intensity of $323,95-1767,43$ lux or $3.24 \%$ 8.84\%. In East Kalimantan regeneration of ulin found at temperature of $27,1-29,9^{\circ} \mathrm{C}$, humidity $69,2-95,3 \%$, and light intensity 321,0-737,3 lux (Sidiyasa, 2011). These results show that regeneration of ulin need shading for life.

Normally, the natural regenerations were found under tree crown projection. Ulin is included as gap opportunist species, meaning that the young regenerations need shading and the mature trees of ulin need enough light for life.

Table 1. Measurement of micro climate where ulin regeneration was found

\begin{tabular}{ccccc}
\hline Location & $\begin{array}{c}\text { Temperature } \\
\text { (C) }\end{array}$ & $\begin{array}{c}\text { Humidity } \\
(\mathbf{\%})\end{array}$ & $\begin{array}{c}\text { Light } \\
\text { Intensity (lux) }\end{array}$ & $\begin{array}{c}\text { Light } \\
\text { Intensity (\%) }\end{array}$ \\
\hline Kintab & 27,12 & 83,76 & 323,95 & 3,24 \\
Kotabaru & 31,00 & 66,43 & 1767,43 & 8,84 \\
\hline
\end{tabular}

Table 2. Number of individuals of ulin in each growth stage at Kintap and Serongga plots

\begin{tabular}{ccccc}
\hline \multirow{2}{*}{ Growth Stage } & \multicolumn{2}{c}{ Kintap (Tanah Laut Regency) } & \multicolumn{2}{c}{ Serongga (Kotabaru Regency) } \\
\cline { 2 - 5 } & $\begin{array}{c}\text { Plot } 1 \\
\text { Number of individual } \\
\text { (n/ha) }\end{array}$ & $\begin{array}{c}\text { Plot } 2 \\
\text { Number of individual } \\
\text { (n/ha) }\end{array}$ & $\begin{array}{c}\text { Plot 1 } \\
\text { Number of individual } \\
\text { (n/ha) }\end{array}$ & $\begin{array}{c}\text { Number of } \\
\text { individual (n/ha) }\end{array}$ \\
\hline Seedling & 4 & - & 5 & 3 \\
Sapling & 46 & 24 & 19 & 3 \\
Pole & 5 & 6 & 5 & - \\
Tree & - & - & - & - \\
\hline
\end{tabular}

Information: Kintap; plot1: slope of 0-5\%, plot2: slope of 18.15\%, Serongga; plot1 and plot2: slope of 0-5\% 
Table 3. Volume of ulin for pole stage and tree stage

\begin{tabular}{lcccc}
\hline Location & $\begin{array}{c}\text { Volume } \\
\text { of pole } \\
\left(\mathbf{m}^{\mathbf{3}}\right)\end{array}$ & $\begin{array}{c}\text { Volume } \\
\text { of pole } \\
\left(\mathbf{m}^{\mathbf{3}}\right)\end{array}$ & $\begin{array}{c}\text { Volume } \\
\text { of tree } \\
\left(\mathbf{m}^{\mathbf{3}}\right)\end{array}$ & $\begin{array}{c}\text { Volume } \\
\text { of tree } \\
\left(\mathbf{m}^{\mathbf{3}}\right)\end{array}$ \\
\cline { 2 - 5 } & Plot $\mathbf{1}$ & Plot $\mathbf{2}$ & Plot $\mathbf{1}$ & Plot $\mathbf{2}$ \\
\hline $\begin{array}{l}\text { Kintap } \\
\text { (Tanah }\end{array}$ & 1,62 & 0,71 & $\mathrm{nf}$ & $\mathrm{Nf}$ \\
$\begin{array}{l}\text { Laut } \\
\text { Regency) } \\
\text { Serongga } \\
\text { (Kotabaru }\end{array}$ & 0,21 & 0,56 & 0,99 & $\mathrm{nf}$ \\
Regency) & & & & \\
\hline nf: not found & & & \\
\hline
\end{tabular}

Table 3 shows that the potency of ulin is very low and ranged from $0.21 \mathrm{~m} 3$ to $1.62 \mathrm{~m}^{3}$ per hectare of pole stage and $0.99 \mathrm{~m} 3$ per hectare of tree stage. Most of stumps found in both location is with diameter below $60 \mathrm{~cm}$. The potency and population of ulin decreased significantly because illegal logging activities are still common in these locations.

Increase demand of ulin wood for various purposes has resulted in tree felling in natural forest without considering its sustainability. Felling of ulin was conducted not only in production forest but also in protected forest. Although some regulation concerning the prohibition of logging ulin has been made by both central and local government, ulin illegal logging is still continuing.

Implication to Building Construction. Environmental condition of rivers and swamps causes problem for Banjarese who want to build settlement. The construction materials entirely use local materials that can overcome the problems caused by water, so they use ulin and galam as an option on the potential local wood (Muchamad \& Mentayani, 2010). But increase the demand of ulin for building settlement is not balance with growth rate of ulin and low of awareness of local people to fell based on limit diameter $(>60 \mathrm{~cm})$. Some policies should be made by both the central and local government for the sustainability of ulin.

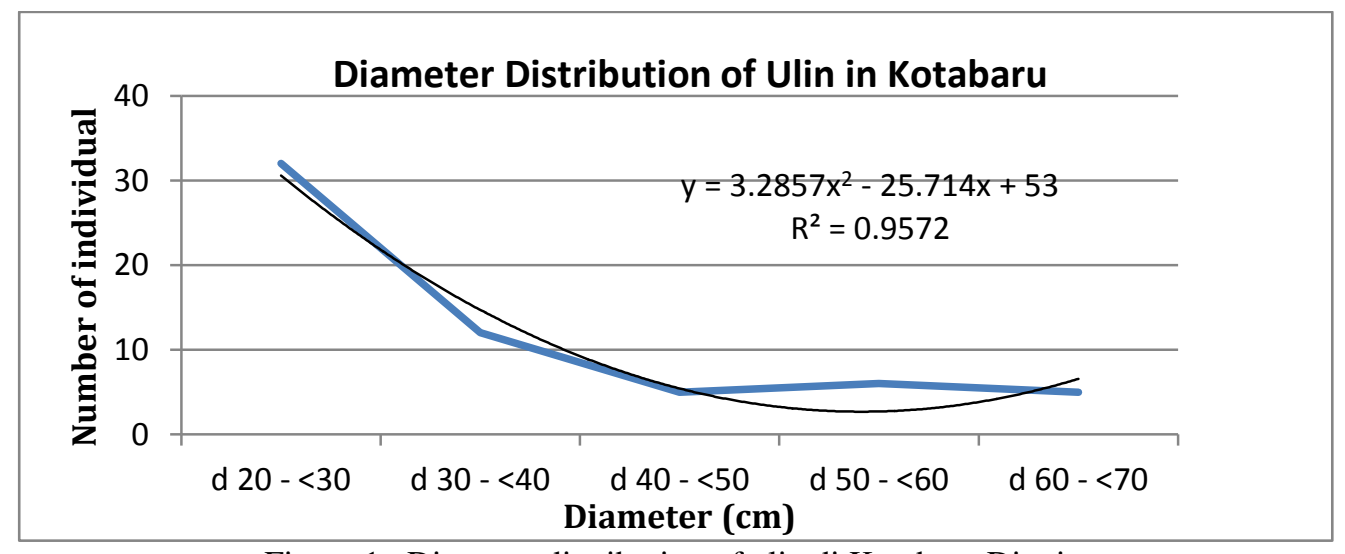

Figure 1. Diameter distribution of ulin di Kotabaru District

Until present day that is very difficult to find $\log$ of ulin on limit diameter $(>60 \mathrm{~cm})$. Result of survey from Faculty of Forestry Unlam at tropical production forest (135 ha) in Kotabaru district shows that ulin with limit diameter of $60 \mathrm{~cm}-70 \mathrm{~cm}$ found only 5 individuals. Potential stands of ironwood in the logged forest is quite small with an average of 1 tree / ha for the class of diameter $>60 \mathrm{~cm}$ and 2 trees / ha for $>50 \mathrm{~cm}$ diameter classes. For the $10-30 \mathrm{~cm}$ diameter class is average of 4 trees / ha and diameter classes > $30 \mathrm{~cm}$ averaged 3.4 trees /ha. The average of increment for ulin is ranged from 0.19 to 0.27 $\mathrm{cm} /$ year and volume increment between 0,146 to $0,523 \mathrm{~m} 3 /$ ha (Wahjono \& Imanuddin, 2011).

Total of needs for the entire sawmill industry in South Kalimantan average 50,20 m annually. Raw material of ulin that still exists today is estimated to come from East Kalimantan and Central Kalimantan, because 
the areas of tropical forest in both provinces are larger than South Kalimantan but geographically closest.

\section{DISCUSSION}

Result of research shows the population of ulin keep decreasing. The amount of natural regeneration ranged from 3-5 individuals/ha for seedlings and 3-46 individuals/ha for sapling. The natural regeneration for ulin is very low, because it is often lose the competition with other vegetations or very close of crown shading projection.According of Sidiyasa et. al. (2009), low of regenerations is caused by attacking of pests (especially squirrels and raccoons) that eat the young seeds. In East Kalimantan, many of fallen fruit were eaten by porcupine while the other got rotten due to diseases and fungi (Effendi, 2004).

The natural regeneration of a species is very important for its sustainability especially its quantity, quality, and distribution. Lack of natural regenerations is increasing scarcity of ulin. According to the Directorate General of Forest SK No.200/Kpts-IV/1994, the number of individual of seedlings in order to maintain the sustainability of potential stand a minimum of 1000 stems / ha and for the sapling stage is 240 stems / ha.

The pole stage of ulin is very rarely found in both locations. Number of poles found in both locations are ranged $5-6$ individuals/ha, and both locations were not found tree stage of ulin. According to Sidiyasa (2009), pole stage of ulin at several locations in Kalimantan were about 41-65 individuals/ha.

\section{CONCLUSIONS}

1. Banjarese people in South Kalimantan need ulin (ironwood) to build a house and has become a culture especially those residing in the wetlands, but the potential ironwood till today is very low, so it is necessary to substitute alternative wood.

2. Technical management to preserve and cultivate ulin is needed to avoid extinction.
3. Commitment from all stakeholders (government, employers, and community) to preserve ironwood, and strengthened low enforcement for illegal loggers are needed.

\section{REFERENCES}

Effendi R., 2004. Natural Regeration of E. zwageri T. et. B. at Gunung Meratus Protection Forest East Kalimantan-Indonesia

Heyne, K., 1987. Tumbuhan Berguna Indonesia II (Terjemahan). Badan Penelitian dan Pengembangan Kehutanan, Departemen Kehutanan.

Muchamad B. N., and Mentayani I., 2010. Local Wisdom in "Wetland architecture". Paper in University of Gadjah Mada (UGM).

Nogroho, A.W., Junaidah, Siahaan, dan Sofyan, A., 2006. Status Pemeliharaan dan Pengembangan Ulin (Eusideroxylon zwageri T. et. B.) di Sumatera Bagian Selatan. Prosiding Worshop Sehari 20 Desember 2006. Kerjasama Puslitbang Hutan Tanaman dan Tropenbos International, Indonesia.

Sidiyasa, K., T. Atmoko, A. Ma'ruf dan Mukhlisi, 2009. Kajian tentang Keragaman Morfologi, Ekologi, Pohon Induk, dan Konservasi Ulin di Kalimantan. Laporan Hasil Penelitian Kerjasama dengan Departemen Pendidikan Nasional, Balai Penelitian Teknologi Perbenihan Samboja.

Sidiyasa, K., 2011. Sebaran, Potensi dan Pengelolaan Ulin Indonesia. Prosiding Lokarya Nasional Bogor, 18-19 Januari 2011.

Wahjono D., and Imanuddin R., 2011. Sebaran, Potensi dan Pertumbuhan/Riap Ulin (E. zwageri T. et. B.) di Hutan Alam Bekas Tebangan di Kalimantan. Makalah dipresentasikan pada Lokakarya Nasional "Status Konservasi dan Formulasi Strategis Konservasi Jenis-jenis Terancam Punah (Ulin, Eboni, dan Michelia" yang diselenggarakan oleh ITTO Project PD 539/09 rev. 1 bekerja sama dengan Puslitbang Konservasi dan Rehabilitasi, Badan Litbang Kehutanan, Kementerian Kehutanan RI, pada tanggal 18-19 Januari 2011, di Bogor. 
Journal of Wetlands Environmental Management

Vol 1, No 1 (2013) 61 - 64

http://dx.doi.org/10.20527/jwem.01.01.03 